\title{
Feasibility Analysis of Leaf-Based Moringa oleifera Plantation in the Nigerian Guinea Savannah: Case Study of University of Ilorin Moringa Plantation
}

\author{
${ }^{1}$ Animashaun, J.O and ${ }^{2}$ Toye, A.A \\ Department of Agricultural Economics \& Farm Management, University of Ilorin, Nigeria, \\ Department of Animal Production, Faculty of Agriculture, University of Ilorin, P.M.B 1515, llorin, \\ Nigeria \\ reals4u@yahoo.com, +234-8038-550-618; ayo.toye@btinternet.com, +234-813-1011-392
}

\begin{abstract}
This study examined the profitability and economic feasibility of a leaf-based Moringa production and processing under a plantation system in the Nigerian guinea savannah using the University of llorin Moringa Plantation as a case study. To achieve this objective, data on production and processing cost and revenue for the 2011/2012 planting season were collected and a simulated 10-year production and cost and revenue scenarios were scheduled based on the assumption of a constant cost and cash inflow over the same period. The cost-benefit was reported using the Return on Investment (ROI), Benefit Cost Ratio (BCR) and the Net Present Value (NPV) analyses. Result indicated an estimated average net profit of $\$ 827,109$ (USD5, 137) ha/annum from a Total production cost of $A 1,371,360$ (USD8, 580) ha/annum and a gross revenue of $\mathrm{A2}, 200,000.00$ (USD13,750) ha/annum derived from the sale of an average of $110 \mathrm{~kg}$ of processed dry leaf powder output. This indicates the relative profitability of the enterprise. Furthermore, at varying discount rates of $17.5 \%, 20 \%, 22.5 \%$, and $25 \%$, the BCR indicated that for every $\mathrm{A1}$ invested in cost, the investor could realize 11.60 in returns, the ROI indicate a profit return turnover of $26.7 \%$ of the cost of investment and a NPV estimate at the end of the 10-year period considered the project to be financially worthwhile. Based on these findings, this study recommends the encouragement of Moringa production and value addition development due to the potential it portends for income generation.
\end{abstract}

Key words: feasibility analysis, Moringa leaf and enterprise

\section{INTRODUCTION}

Moringa oleifera, is a multi-purpose food plant, which originated from India, and is produced and used in many African countries, South America (Nicaragua and Bolivia), and New Zealand. Studies have shown that Moringa is a Relatively inexpensive as a source of nutrition packed food and supplement for humans and animals and is rich in health-promoting phytochemicals, various vitamins and minerals (Becker and Siddhuraju, 2003). Moringa leaves have a characteristic distinctive, strong, mustard-like taste; they are a good source of provitamin A, vitamins B and C, minerals (particular iron) and the sulphur containing amino acids methionine and cystine, and are eaten as a supplement to the major staple foods. In the Northern part of Nigeria, the cooked leaves of Moringa are frequently eaten as the principal ingredient of a sauce. These leaves are generally 
harvested from trees found within household gardens or planted as part of hedges around gardens.

The value chain for Moringa product, if properly developed, offers considerable investment opportunities, and potential job creation, foreign exchange earnings and export diversification for Nigeria. It provides several interesting products, of which leaves and oil seem to be economically most attractive. Moringa products are demanded at the international markets (USA, China, and India) mainly in the form of leaf powder tablets and drinks and are regarded as a healthy nutritious food supplement. The seedcake, a cheap by product of oil extraction can serve as an inexpensive, protein-rich feedstuff for livestock. In several African countries the local market for dried leaves and leaf powder is expanding as awareness of its nutritional benefits increases. Equally, demand is set to rise as the seed oil is used in the cosmetics industries and it is considered an alternative and cheaper source of biodiesel.

Despite the enormous potentials of Moringa, evidence on large scale production of the plant in Nigeria is relatively scanty. This may be due to inconsistent and unrealistic empirical findings on the economic feasibility and profitability of the plant under commercial plantation (Fodl et al, (2001); Gamatie and Saint Sauveur, (2006); Sogbo et al, (2006), Van der Heijden, (2011). In most cases, analysis on economic feasibility of Moringa cultivation did not come from existing Moringa plantations but from controlled and laboratory conditions which often reflect ideal conditions with regard to soil, rainfall, management, and markets etc, which in most cases do not exist in practice. Furthermore, cost and returns analysis of Moringa cultivation have principally been based on data collected from small-scale farmers which might not be representative of actual expected returns on investment as economies of scale might increase profit. Therefore, most published figures on inputs and Moringa yield are assumptions, extrapolations and consequently undependable Van der Heijden, (2011).

This study therefore examined the feasibility of leaf-based Moringa Plantation by the use of empirical data at the University of Ilorin, Ilorin, Nigeria. There is a well established Moringa Plantation at the University which can provide conservative and reliable data on cost and returns on investment which could be used in defining economic feasibility. The resultant feasibility report which is grounded on an empirical data can serves as a robust guide to potential investors, developmental agencies and governmental bodies for further decision making and policy formulation.

\section{An Overview of Management Practices, Economics and Usages of Moringa}

Moringa oleifera belongs to a family of trees that consist of 13 different species. It is native to the sub-Himalayan parts of Northern India, Pakistan, Bangladesh and Afghanistan (Fahey, 2005) and has been cultivated in many parts of the world for millennia particularly, the tropical countries (Fahey, 2005). It is a fast growing soft wood tree that can reach a height of around 10 meters. Several component parts have a huge economic value, including the leaves (dark green, feathery and 1-2 cm long), "flowers (cream coloured, 10-15 cm long) and fruits (or 'pods') it produces. Pods are initially green and turn brown and dry at maturity. Each mature pod contains 15 to 20 seeds. 
Each tree may produce up to $3 \mathrm{~kg}$ of seeds per annum $(10,000-12,000$ seeds or 600 pods at 20 seeds).

Moringa grows best in well-drained soils with $\mathrm{pH}$ of between 5.0 and 9.0 and in temperatures between 25 and $35^{\circ} \mathrm{C}$ and a rainfall range between $250 \mathrm{~mm}$ and 4,000 $\mathrm{mm}$ (Crosby, 2007; Palada and Change, 2003). However, studies have shown that agro-climatic conditions do have an impact on the anti oxidant and proximate composition of the plant (lqbal and Bhanger, 2005). Moringa can be planted from seeds or from cuttings, however, direct seedling is a more preferred choice as the germination rate of Moringa seeds is high (Saint Sauveur and Broin, 2010). Seeds generally germinate within two weeks of sowing and seedlings are trimmed regularly to encourage branching (Amaglo, 2006; Palada and Chang (2003). For leaf production, it has been suggested that Moringa can either be planted as intensive production, semi-intensive production or as part of an agroforestry system, with spacing ranging from $0.75 \mathrm{~m} \times 1 \mathrm{~m}$ to intensive culture of $10 \mathrm{~cm} \times 10$ $\mathrm{cm}$ (Sanchez et al, 2006). High density planting of between 300,000 to 1 million plants per hectare is optimal for biomass production. At this density, harvests need to occur every 35 to 75 days (Amaglo, 2006; Sanchez et al, 2006). For pod production, high density has a negative effect on yields so recommended spacing is $2.5 \mathrm{~m} \times 2.5 \mathrm{~m}$.

Moringa is fairly resistant to pests and diseases since its relatively fast vegetative growth allows it to regenerate quickly from any disturbance. However, fungal diseases like Cercospora spp., Septoria lycopersici, Root rot (Diplodia spp.), Powdery mildew (Levellula taurica, Alternaria solani and insect pest like Grasshoppers, crickets, Termites, caterpillars represent the highest risks for Moringa plantations as they are hard to detect Saint Sauveur and Broin, (2010); Palada and Chang, (2003).

Productivity and reported yield value of Moringa leaf vary widely and are inconsistent across and within the same management practices 
Table 1: Moringa Leaf-Cutting Yields across selected Countries and Management Practices

\begin{tabular}{|c|c|c|c|}
\hline Country & Technique & Yield (mt/ha/yr) & Source \\
\hline Nicarugua & $\begin{array}{l}\text { Intensive ( } 1 \text { million plants/ ha, } 9 \text { harvests per } \\
\text { year, irrigation, fertilization) }\end{array}$ & 580 & Foidl et al (2001 \\
\hline Senegal & $\begin{array}{l}\text { Intensive (1 million plants / ha, } 6 \text { cuttings } \\
\text { per year, irrigation) }\end{array}$ & $40-80$ & Olivier (n.d.) \\
\hline Niger & $\begin{array}{l}\text { Semi-intensive smallholder (1m x 1m, } 18 \\
\text { harvests per year) }\end{array}$ & 47 & $\begin{array}{l}\text { Gamatie and Saint } \\
\text { Sauveur (2006 }\end{array}$ \\
\hline Togo & $\begin{array}{l}\text { Semi-intensive smallholder (1m x 1m, } 7 \\
\text { harvests per year) }\end{array}$ & $5-10$ & Sogbo et al (2006) \\
\hline Benin & $\begin{array}{l}\text { Semi-intensive smallholder ( } 1 \mathrm{~m} \times 1 \mathrm{~m}, 7 \\
\text { harvests per year, irrigation every } 5 \text { days) }\end{array}$ & 6 & $\begin{array}{l}\text { Ogoudadja and } \\
\text { Saint } \\
\text { Sauveur (2006) }\end{array}$ \\
\hline Benin & Intercropping (500 plants / ha, 6 harvests) & $1-2$ & $\begin{array}{l}\text { Ogoudadja and } \\
\text { Saint } \\
\text { Sauveur (2006) }\end{array}$ \\
\hline
\end{tabular}

Source: Muller and Rebelo (Assessed on 06/08/12)

Processing fresh leaves into leaf powder produces around $12.5 \%$ to $15 \%$ of leaf powder per unit of freshleaves.

\section{Table 2: Planting Density and Moringa Leaf Yield}

\begin{tabular}{lll}
\hline Planting density (Plant/ha) & Fresh matter (metric ton/ha) & Dry matter (metric ton/ha) \\
\hline 350000 & 29.7 & 5.05 \\
900000 & 52.6 & 8.94 \\
1000000 & 78.0 & 13.26 \\
\hline
\end{tabular}

Source: Muller and Rebelo (Assessed on 06/08/12)

Detailed processing costs under commercial production are rarely available. However, published figures for production costs under small scale managerial practices were calculated at USD 4.30 per kg of leaf powder in Senegal and in Benin at USD 2.80 (Ogoudaja, 2006). 
Although there are still many gaps with regard to scientific knowledge about Moringa, most researchers agree that this tree has high potentials not only as a food source but also as a 'nutraceutical' (Siddhuraju and Becker, 2003). All parts of the Moringa tree have applications as food, biofuel, forage, plant growth hormone, medicinal, cosmetics, water treatment, Wood Paper and alcohol production applications. The Bark is used in rope making and gum for tanning hides. More importantly, many sources quote that an equal weight of Moringa leaves contain more betacarotene than carrots, more iron than spinach, more potassium than bananas, more Vitamin $\mathrm{C}$ than oranges and more protein than peas' (Palada and Chang, 2003). Given these qualities it is considered to have high potential in combating malnutrition. A review of medicinal literature (Fahey, 2005) summaries the medicinal applications of Moringa as follows; Antimicrobial/ Biocidal agent (especially against bacteria causing gastritis), Asthma, Cancer prevention (Tumor prevention, tumor inhibition, not proven yet in humans), prevention and treatment of Circulatory / Endocrine Disorders, Digestive Disorders, Inflammation, Nervous Disorders, Nutritional, Reproductive Health and Skin Disorders and a booster of immunity. The author however cautioned that most of these results have not been verified through a placebo-controlled, randomized clinical trial, nor published in well-known scientific journals.

\section{METHODOLOGY}

The present study was carried out in Kwara State, Nigeria. The state has two main climatic seasons; the dry and wet season. The natural vegetation comprises wooded and rainforest savanna, with annual rainfall ranging between 1000 to $1500 \mathrm{~mm}$ while the average temperature lies between $30^{\circ} \mathrm{C}$ and $35^{\circ} \mathrm{C}$. Over 90 percent of the rural populace is involved in farming (KWADP, 1999). Agriculture is the mainstay of the economy in Kwara State. Varieties of cash and food crops produced include cereals, tubers, cocoa, kola-nut and livestock (KWADP, 1999).

Specifically, primary data was purposively sourced from the University of Ilorin Moringa Plantation located in Kwara State, Nigeria. The University has an established pilot-scale Moringa plantation. Moringa seedlings were transplanted from nursery to the field at a planting density of 4,444 Moringa seedlings per hectare. Data collected were on cost of fixed and variable inputs used in the management and production as well as estimate of yield of leaf output in kilogram, price per unit output of processed leaves and the total revenue from the sale of dried Moringa leaf. Data on production cost used were estimates of land lease, land clearing, land preparation, supervision, blender, fertilizer, herbicide, seedling planting, Planning and management (logistic), Risk management and operational staff. Data on benefits were equally collected on output of leaf yield per annum, unit sale price of packaged Moringa dried leaf at the current market price in llorin market, cost of packaging and processing of Moringa leaf powder.

\section{LIMITATIONS OF THE STUDY}

The authors of this study consider this study representative of what Moringa farmers in the study area may anticipate in terms of costs and yield. However, due to some underlying basic assumptions used in gathering the data used in this study, cautions that different factors may alter the costs and benefits reported in this study when compared with a particular individual's 
operation. The primary value of this report is to identify the type of inputs, yields, and costs considered to be typical of well-managed Moringa enterprise in the guinea savannah. As such, it should be helpful in estimating the physical and financial requirements of Moringa plantations in several other plantations in the same agro-ecological zone to test the representativeness of the data reported in this study.

\section{Analytical Technique}

Empirical data formed the foundation for deriving the economic indicators used in estimating the profitability and economic feasibility of the Moringa dried leaf production under plantation system venture. These economic indicators are;

\section{Cost and Returns Analysis}

Net Benefit = Gross Revenue-Total Production Cost

Where, Gross revenue = Quantity x Price;

Total Production Cost = Total Fixed Cost + Total Variable Cost

\section{Benefit-Cost Ratio (BCR)}

The Investment Decision Model also utilizes the Benefit-Cost Ratio, which is another indicator of the worthiness of an investment decision. It is given as the ratio of the sum of discounted benefits to the sum of discounted costs. Thus, for a cycle of 10 years duration, the benefit-cost ratio can be represented by the formula:

$\mathrm{BCRI}, \mathrm{t}=\sum_{I=0}^{10}\left(\frac{D R E V i, t}{D T C i, t}\right)$

Where:

DREV $_{i, t}=$ discounted revenue (benefits) per hectare from i-year-old Moringa in year $\mathrm{t}$;

$\mathrm{DTC}_{\mathrm{i}, \mathrm{t}}=$ discounted total costs per hectare from i-year-old Moringa in yeart;

The decision rule is that for any project to be economically viable, the ratio must be greater than unity (Brealey and Myers, 1991; Bierman and Smidt, 1988).

\section{Returns on Investment Analysis (ROI)}

The Return on Investment (ROI) is similar to $B C R$, but compares the net benefit (total discounted benefits minus total discounted costs) to costs. To estimate the ROI, we first calculate the net benefits, and then divide the net benefits by the total costs. The result of the ROI is typically expressed as a percentage. The ROI indicates how much of the investment policymakers can expect to receive as a benefit. 


\section{The Discounted Net Present Value (NPV)}

This discounts the values of future earnings and losses to provide for today's values. For this analysis, an appropriate discount rate needs to be chosen. Following Brealey and Myers, 1991 and Luehrman, 1998) the net present value of the expected cash inflow from one hectare of Moringa in year tfor a 10 years duration amounts to:

$V=\int_{0}^{\infty} e^{-p t} E[(P t Q w, t-(w, t)-(P t Q 0, t-C o, t)] d t$

Where $p$ is the real discount rate; $t$ is the time period; $E$ is the expectations operator; $P$ is the output price; $Q$ is the output quantity; $C$ is the variable costs of production; and subscripts w and o indicate production with and without the investment respectively. The acceptance rule adopts projects where incremental net revenues are greater or equal to incremental investment costs $(V=I)$. The formal selection criterion for the net present value is to accept investments with net present value greater than zero. Hence the revenues are insufficient to allow for the recovery of the investment. An investment is technically and economically feasible if the net present value is positive. We decided on a realistic discount rate of $17.5 \%, 20 \%, 22 \%$ and $25 \%$ based on the prevailing interest rates available for medium-term loans in commercial banks in Nigeria.

\section{RESULTS AND DISCUSSION}

Gross Margin Analysis of Moringa Leaf Production and Processing

The depreciation schedule of inputs used in Moringa production and processing activity is presented in Table 3.

Table 3: Depreciation Schedule for Fixed Inputs used in Moringa Leaf Production and Processing

\begin{tabular}{llllll}
\hline Items & $\begin{array}{l}\text { Expected } \\
\text { lifespan (yrs) }\end{array}$ & Quantity & $\begin{array}{l}\text { Unit cost } \\
(\mathrm{N})\end{array}$ & $\begin{array}{l}\text { Total cost } \\
(\mathrm{N})\end{array}$ & $\begin{array}{l}\text { Annual } \\
\text { depreciation }(\mathrm{N})\end{array}$ \\
\hline Blender & 10 & 1 & 150,000 & 150,000 & 15,000 \\
Knapsack & 10 & 1 & 20,000 & 20,000 & 2,000 \\
sprayer & & & & & \\
Spade & 10 & 2 & 1,000 & 2,000 & 200 \\
Machetes & 10 & 2 & 1,000 & 2,000 & 200 \\
Hand trowels & 10 & 5 & 500 & 2,500 & 250 \\
\hline
\end{tabular}

Source: University of llorin Moringa Plantation, 2011/2012 season

As revealed in the Table, the inputs are expected to have an average lifespan of 10 years and are assumed to possess zero salvage value at the end of their productive use. 


\section{Estimated Average Annual Cost Analysis of Moringa Leaf Production/ha}

The result of the estimated fixed and operating costs of Moringa dry leaf production and processing are presented in Table 4.

\section{Table 4: Estimated Average Annual Cost Analysis of Moringa Leaf Production/ha}

\begin{tabular}{llll}
\hline Items & $\begin{array}{l}\text { Cost ( )I } \\
\text { Annum }\end{array}$ & $\begin{array}{l}\text { \% of total } \\
\text { Investment cost }\end{array}$ & Total \\
\hline Cost & 15,000 & 0.0542 \\
Land-lease & 9,600 & 0.0347 \\
Land clearing & 120,000 & 0.4338 \\
Factory house rent & 84,710 & \\
Plantation management and & & 0.3062 \\
logistic & 30,000 & \\
Pest and disease prevention & & 0.1085 \\
and control & 15,000 & 0.0542 \\
Blender & 2,000 & 0.0072 \\
Knapsack sprayer & 200 & 0.0007 \\
Spade & 200 & 0.0007 \\
Machetes & 250 & 0.0009 \\
Hand trowels & & \\
& 444,400 & 0.406 \\
Seedlings (N100 each) & 432,000 & \\
Labour (2 permanent workers & & \\
for weeding, harvesting and & & \\
processing)@ N18,000 & & 0.395 \\
each/month & & 0.027 \\
Utility bills & & 0.110 \\
Labeling and Packaging & 30,000 & 120,000 & 0.014 \\
Fertilizer (@N100/kg) & 15,000 & \\
Fertilizer application 2 man-day & 2,000 & 0.001 \\
Miscellaneous expenses @ 4\% & 51,000 & 0.048 \\
of cost & & \\
Total Operating Cost & & \\
Total Production Cost (TPC) & & \\
\hline
\end{tabular}

Source: University of Ilorin Moringa Plantation, 2011/2012 season

As shown in the Table, the estimated annual mean investment outlay is N276, 960 (Table 4). This covered the cost of land lease, Management and logistics, factory rent, pest and disease prevention and control and depreciated fixed inputs of production. The fixed cost outlay represents about $20 \%$ of the total production cost of the Moringa leaf production and processing enterprise. The Table also reveals the estimated annual mean operating cost of leaf based Moringa plantation production and processing enterprise. The Table indicates an average mean operating cost of $1,094,400$ which represents about $80 \%$ of the Total production cost outlay (Table 
Animashaun and Toye

4). This cost covers seedling cost, labour cost, labeling and packaging cost, fertilizer, utility and other miscellaneous expenses at $4 \%$ of the Total production cost.

Gross Margin Analysis of a Leaf-based Moringa Plantation Production and Processing

The gross margin analysis of Moringa dried leaf production and processing enterprise under a Plantation system is presented in Table 5.

Table 5: Estimated Gross Margin Analysis of Moringa Leaf Production and Processing/ha

\begin{tabular}{lllll}
\hline Items & Quantity $(\mathrm{Kg})$ & Unit Price (N) & Total & Net profit \\
\hline $\begin{array}{l}\text { Dry Leaf Yield of } \\
\text { Moringa crop/ha }\end{array}$ & 120 & & & \\
$\begin{array}{l}\text { Gross revenue (from } \\
\text { actual sales) }\end{array}$ & 110 & 20,000 & $2,200,000$ & \\
Total production cost & & & & \\
\end{tabular}

Source: University of Ilorin Moringa Plantation, 2012/2012 season

According to the Table, revenue is derived from the sales of the dried leafy part of the Moringa plant. Actual revenue from the sale of $1 \mathrm{~kg}$ of Moringa dried leaves was ?20,000.00 and at a saleable average of $110 \mathrm{~kg}$ per ha, a gross revenue of $\$ 2,200,000(\$ 13,750)$ is expected /ha/annum (Table 5). By deducting costs from the gross revenue, a mean net profit of ?828,640 (USD 5,137) was obtained from 1 hectare per annum.

\section{Feasibility Analysis of Moringa Dried Leaf Production under a Plantation System}

Feasibility analysis involves the determination of how viable an enterprise is. The Net Benefit analysis in the preceding section gives us a rough estimate of profitability of the Moringa enterprise but, it lacks a very important component, namely time. Because money has time value, the best way to compare cash flows that occur at different times is to convert all those cash flows to their present values in order to determine its economic feasibility. The techniques used in this study for the determination of enterprise viability are the Net Present Value (NPV), Returns on Investment (ROI) and Benefit-Cost Ratio (BCR) analysis.

The result of the economic feasibility indicators; the NPV, BCR and ROI are presented in Table 6. 
Animashaun and Toye

Table 6: Estimated Net Present Value (NPV) of a Leaf-Based Moringa Production and Processing at Discount rates of $17.5 \%, 20 \%, 22.5 \%$ and $25 \%$

\begin{tabular}{|c|c|c|c|c|c|c|c|c|}
\hline \multirow[t]{2}{*}{ Year } & \multicolumn{2}{|c|}{ @ 17.5 Discount rate } & \multicolumn{2}{|c|}{ @ 20\% Discount rate } & \multicolumn{2}{|c|}{$\begin{array}{l}@ 22.5 \% \text { Discount } \\
\text { rate }\end{array}$} & \multicolumn{2}{|c|}{ @ 25\% Discount rate } \\
\hline & $\begin{array}{l}\text { Cash } \\
\text { Inflow }\end{array}$ & Cost & $\begin{array}{l}\text { Cash } \\
\text { inflow }\end{array}$ & Cost & $\begin{array}{l}\text { Cash } \\
\text { inflow }\end{array}$ & Cost & $\begin{array}{l}\text { Cash } \\
\text { inflow }\end{array}$ & Cost \\
\hline 1 & 1872340 & 1167114 & 1833333 & 1142800 & 1760000 & 1097088 & 1760000 & 1097088 \\
\hline 2 & 1593510 & 993307 & 1527778 & 952333.3 & 1466667 & 914240 & 1410256 & 879076.9 \\
\hline 3 & 1356350 & 845474 & 1271676 & 792693.6 & 1202186 & 749377 & 1128205 & 703261.5 \\
\hline 4 & 1154249 & 719496 & 1062802 & 662492.8 & 977777.8 & 609493.3 & 901639.3 & 562032.8 \\
\hline 5 & 982581 & 612487 & 887096.8 & 552967.7 & 797101.4 & 496869.6 & 721311.5 & 449626.2 \\
\hline 6 & 836183 & 521231 & 735786 & 458648.8 & 650887.6 & 405727.8 & 577427.8 & 359937 \\
\hline 7 & 711513 & 443518 & 614525.1 & 383061.5 & 531401 & 331246.4 & 461215.9 & 287496.9 \\
\hline 8 & 605560 & 377475 & 512820.5 & 319664.3 & 433925 & 270485.2 & 369127.5 & 230094 \\
\hline 9 & 515343 & 321236 & 427184.5 & 266283.5 & 354267.3 & 220830.9 & 295302 & 184075.2 \\
\hline 10 & 438596 & 273397 & 355412 & 221544.4 & 289093.3 & 180205 & 236305 & 147299.7 \\
\hline Total & 10066225 & 6274735 & 9228414 & 5752490 & 8463306 & 5275563 & 7860791 & 4899988 \\
\hline NPV & \multicolumn{2}{|c|}{$\mathrm{N} 3,791,490$} & \multicolumn{2}{|c|}{$\mathrm{N} 3,475,924$} & \multicolumn{2}{|c|}{$\mathrm{N} 3,187,743$} & \multicolumn{2}{|c|}{$\mathrm{N} 2,960,803$} \\
\hline BCR & \multicolumn{2}{|c|}{1.604} & & & & & & \\
\hline ROI & \multicolumn{2}{|c|}{$27.6 \%$} & & & & & & \\
\hline
\end{tabular}

Source: University of llorin Moringa Plantation, 2011/2012 season

As shown in Table 6, it is observed that the Moringa leaf production enterprise at discount rates of $17.5 \%, 20 \%, 22.5 \%$, and $25 \%$ is feasible and viable. The returns on Investment (ROI) of University of llorin Moringa Plantation were $27.6 \%$. This implied that the investment (i.e., the cost) will generate a return (i.e., net benefit) that amounts to $27.6 \%$ of the cost of the investment. The ROI is a relative measurement of how much of the investment investor can expect to receive as a benefit. If the ROI is positive, the benefits exceed the costs and the investment should be considered. A negative ROI means that the costs outweigh the benefits. An ROI of 0 means the benefits equal the costs. 
Equally from Table 6, we estimated the BCR at 1.6 at the same prevailing discount rates. A benefitcost ratio of 1.60 means investors can expect ?1.60 in benefits for every 1 in costs. Clearly, because the BCR is greater than 1, the benefits outweigh the costs and the investment is considered relatively feasible. Had the ratio been less than 1 , the costs would outweigh the benefits and alternative advice would be followed as regards feasibility of project. If the BCR is equal to 1 , the benefits equal the costs.

The estimated Net Present Value of a hectare of Moringa Plantation at 17.5\%,20\%, 22.5\% and $25 \%$ discount rates were \$3,791,490 (\$23,696), \$3,475,924 (\$21,999.11), \#3,187,743 $(\$ 20,175)$, and $\mathrm{N2}, 960,803(\$ 18,739)$. This value reflects the absolute net benefits of the Moringa Plantation in Naira terms. A positive NPV means that benefits outweigh costs and the investment should be considered. A negative NPV means that the costs outweigh the benefits. An NPV of 0 means the benefits are equal to the costs.

This result of our analysis confirms the economic sustainability prospect of the University of llorin, Moringa Plantation Management system. The Returns On Investment (ROI analysis), Benefit Cost Ratio Analysis and the NPV all confirmed positive and hence we accept the decision that the Moringa enterprise is a feasible enterprise at prevailing discount rates.

The analysis in this study is premised under the following modest and realistic facts:

1. a total of two harvests leaf is made each year and maintained for the 10 year period;

2. the analyses was based on discount rates of $17.5 \%, 20 \%, 22.5 \%$ and $25 \%$;

3. the harvested part of the Moringa tree processed for sale was exclusively the leafy part, and the stalk, stem and other fibrous part were left out;

4. a total of 4,444 Moringa seedlings were established on 1 ha of plantation;

5. based on the local market demand in University of Ilorin, a modest sale of $110 \mathrm{~kg}$ of dried Moringa leaf is estimated to be absorbed each year and

6. a kilogram of dried Moringa leaf powder is sold for $\$ 20,000.00$.

\section{CONCLUSION AND RECOMMENDATIONS}

This study conducted a 10-year economic feasibility analysis of production and processing of leafbased Moringa enterprise under Plantation system using primary data and simulated estimates from University of llorin Moringa Plantation. The result showed that a mean annual net profit of A828,640 (USD 5,137) was obtained from one hectare and cumulative net returns of ?8,286,400. However, at varying discount rates of $17.5 \%, 20 \%, 22.5 \%$ and $25 \%$, the Benefit Cost Ratio indicated that for every $\$ 1$ invested in cost, the investor could realize ?1.60 in returns indicating the relative profitability of the enterprise. Equally, the Return on Investment Analysis indicated that the enterprise could generate a return (i.e., net benefit) that amounts to $27.6 \%$ of the cost of the investment. Finally, the NPV estimates reflect that the Moringa Production and Processing enterprise under Plantation system benefits outweigh costs and the investment should be considered.

This study, which is based on empirical and some estimations show the type of inputs, yields, and costs considered to be typical of well-managed Moringa enterprise in the guinea savannah; hence 
it is meant to be an investment guide for prospective investors in to the Moringa plantations enterprise. Although it still remains unclear what the yield and profitability results would be if there are other products of interest aside from the leaves which this study focused on and what would be the effect of intercropping and planting Moringa under an irrigation system on yield and profitability.

Given the feasibility of this enterprise and the potential it carries for sustainable development, income generation and job creation; it is recommended that governments and non-governmental bodies should encourage Moringa production, consumption and value addition activities with the ultimate aim of nutritional security, youth empowerment, liberation of rural communities from existing poverty traps and export diversification in Nigeria.

The relatively high operating expenses of Moringa leaf value chain development could serve as a disincentive for would-be Moringa farmers who may be resource-poor, hence, commercial banks should be compelled by legislation to reserve a reasonable portion of their portfolios for Moringa value chain development at relatively low interest rates In other words, this study advocates for a type of selective credit policy which would make funds to be available to interested individuals who wish to venture into this enterprise. To facilitate this, farmers may be formed into cooperatives with each group focusing on a particular segment of the Moringa value addition process from input provision to production, processing and marketing.

Furthermore, it is recommended that a follow-up study of the estimate of the true size of Moringa leave market, demand and supply elasticities and requirements for growth which should be in line with any increase in production of the leaf product be conducted. The required studies are now underway.

\section{REFERENCES}

Amaglo, N. K., Timpo, G. M. , Ellis W.O and Bennett, R.N. (2006) "Effect of Spacing and Harvest Frequency on the Growth and Leaf Yield of Moringa (Moringa oleifera Lam), a Leafy Vegetable Crop". In: "Moringa and other highly nutritious plant resources: Strategies, standards and markets for a better impact on nutrition in Africa". Accra, Ghana, November 16-18, 2006. Available from: http://www.moringanews.org/ biblio_en.html Accessed on January 10, 2012

Bierman, H. J. and Smidt, S. (1988). The Capital Budgeting Decision New York, Macmillan Publishing $\mathrm{C} 0$. Inc.

Brealey, A. R. and Myers, S. C. (1991). Principles of Corporate Finance United States of America, McGraw-Hill, Inc.

Crosby, G.W. (2007) Soilless Culture of Moringa (Moringa oleifera Lam.) for the Production of Fresh Biomass. PhD Thesis 
Animashaun and Toye

Fahey, J.W. (2005) Moringa oleifera: "A Review of the Medical Evidence for Its Nutritional, Therapeutic, and Prophylactic Properties". Part 1 Trees for Life Journal 1(5): 1-13

Foidl N., Makkar H.P.S. and Becker K. (2001) "The Potential of Moringa Oleifera for Agricultural and Industrial Uses". In: What development potential for Moringa products? October 20th - November 2 $2^{\text {nd }} 2001$. Dar Es Salaam. Available from: http://www.moringanews.org/biblio_en.htmlAccessed on January 10, 2012

Gamatie, M. and Saint Sauveur, A. (2006) "Technical and economic sheet on the conditions for production and marketing fresh Moringa leaves in NIGER". Moringa News. Available from: http://www.moringanews. org/biblio_en.htmlAccessed on March 10, 2012

Gittinger, J. P. (1989), "Economic Analysis of Agricultural Projects". The John Hopkins University Press, London. 1989: 299-362.

Gotsch N., and Burger, K. (2001) "Dynamic Supply Response and Welfare Effects of Technological Change on Perennial Crops: The Case of Cocoa in Malaysia". American Journal of Agricultural Econonomics; 83: 272-285.

Van der Heijden, T., Hendriks, F, Hoek, P, Lysen, G. and Meijers, R. 2011. "Moringa oliefera for a healthy Future. Water purification using Moringa oleifera seeds. RSG Pantarijn, Wageningen. $23 \mathrm{pp}$.

Iqbal, S. and Bhanger, M.I. (2006) "Effect of season and production location on antioxidant activity of Moringa oleifera leaves grown in Pakistan", Journal of Food Composition and Analysis 19 (2006) 544551

Ogoudadja, D. and Saint Sauveur, A. (2006), "Technical and economic sheet on the conditions for production and marketing fresh Moringa leaves in BENIN". Moringa News. Available from:http://www.moringanews. org/biblio_en.html

Palada, M. C. and Chang, L. C. (2003). "Suggested Cultural Practices for Moringa. International Cooperators Guide". March 2003. AVRDC publication number 03-545.

Reyes Sanchez, N., Ledin, S. and Ledin, I. (2006). "Biomass production and chemical composition of Moringa oleifera under different management regimes in Nicaragua", Agroforestry Systems (2006) 66:231242. 
Saint Sauveur, A. and Broin, M. (2010) "Growing and processing Moringa leaves". Published by CDE CTA MoringaAssociation of Ghana Moringanews. Assessed on 08/10/2010 from http://www.anancy.net/documents/file_en/moringawebEN.pdf

Siddhuraju, P.and Becker, K. (2003), "Antioxidant Properties of Various Solvent Extracts of Total Phenolic Constituents from three Different Agroclimatic Origins of Drumstick Tree (Moringa oleifera Lam.) Leaves". J. Agric. Food Chem. 51, 2144-2155

Muller, I. and Rebelo, C (Undated): Moringa the Current Market and Future Potential. A study carried out for EcoPlanet Group. Accessed on www.siteserver2.co.uk/leoneresources/downloads/moringamarketreview.pdf on 06/08/12

Luehrman, T. (1998). Investment Opportunities as Real Options: Getting started on the Numbers Harvard Business Review, July-Aug. 76 (4): 51-67. 